\title{
In-patient satisfaction with nurse caring in Southeast Sulawesi Provincial Hospital
}

\author{
La Rangki ${ }^{1 *}$; Ulfah Dayanti ${ }^{2}$ Asriati $^{3}$ \\ 1*), 2, 3 Universitas Halu Oleo
}

\section{ARTICLE INFO}

Article history:

Received April 25, 2019

Revised May 15, 2019

Accepted May 23, 2019

\section{Keyword:}

Caring Behavior

Nurses

Patients Satisfaction

*) corresponding author

Program Studi Ilmu Keperawatan Fakultas Kedokteran Universitas Halu Oleo

Kampus Hijau Tridharma Anduonohu

Kendari Sulawesi Tenggara

Email: rangki1979@gmail.com

DOI:https://doi.org/10.30604/jika.v4i2.192

\begin{abstract}
A B S T R A C T
The nurse has the most important role in the health sector. In providing nursing care, nurses must have a caring attitude, because caring includes relationships between humans and influences on service quality and patient satisfaction. This research aim to know Relationship of caring behavior of nurses with patient satisfaction in the Laika Waraka Non Surgical In patient Room at the Bahteramas General Hospital Of Southeast Sulawesi Province. This research was an analytic observational study with cross sectional approach. Sampling technique is done by accidental sampling as many as 67 respondents. The results of the study using the chi square test. Respondents who argued that nurses caring behavior was enough amounted to 44 respondents $(65,6 \%)$ and respondents who exppressed satisfaction with health services amounted to 47 (70,1\%).Thus, there is relationship of caring behavior of nurses with patients satisfied in the Laika Waraka non surgical inpatient room at Bahteramas General Hospital Of Southeast Sulawesi Province. Suggestion for nurses to cultivate caring behavior in the provision of daily services in particular more timely in providing services so that to improve the quality of hospital service, particularly in nursing care field.
\end{abstract}

This is an open access article under the CC-BY-SA license.

\section{INTRODUCTION}

Nursing services are the performance of nursing services with the appearance of the work or services that have been provided to individuals or groups. Appearance is the process, manner, action, action and selfimage of something or an individual, besides the notion of appearance includes many things. Not only a matter of fashion, cleanliness, neatness, expression: smile, frown, friendly and skilled (Sabarguna BS, 2005).

Patient satisfaction is a reflection of the quality of health services they receive. The quality of health services refers to the level of 
perfection in providing health services in every patient. The more perfect the satisfaction, the better of quality toward health services. However, relatively good service quality may not be able to satisfy patients. Generally, patients cannot assess technical competence, so they assess the quality of service from non-technical characteristics or interpersonal relationships and service convenience (Supartiningsih, 2017). Providing the highest quality service, is not something that is easy for the hospital manager because the service provided by the hospital involves the quality of life of its patients so that if there are errors in medical or nursing actions can have a negative impact on patients. The impact can be in the form of sick patients getting worse, disability and even death (Jacobalis, 1995).

Patients who come to the hospital with various complaints will experience emotional problems, such as anxiety about pain that is felt, irritability and anger, and lack of concentration. Emotional problems of patients can occur because of the fear felt, do not know the diagnosis of the disease, and have not received therapy. Nurses who have a concern in providing nursing care to patients in the hospital are nurses who are caring attitude. (Supartiningsih, 2017). This is in line with research (Shirly, 2012) about the level of patient satisfaction in orthopedics with the care of nurses at the Science University of Malaysia Hospital. Attention, compassion and empathy. Research on nurses caring behavior has been done by (Siswati S, 2002) in Fatmawati General Hospital. This research was conducted to describe nurses caring behavior based on 10 caring behaviors namely forming a humanistic-altruistic value system, instilling beliefs and hopes, developing sensitivity for oneself and others, fostering relationships of mutual trust and mutual assistance, enhancing and receiving expressions of positive and negative feelings , using systematic problem solving methods, enhancing interpersonal teaching-learning processes, providing an environment that supports, protects and improves mental, sociocultural, spiritual, helps in meeting basic human needs, develops the existentialphenomenological power factor (Watson, 2005). The results obtained by nurses caring very bad. Only $19 \%$ of patients were assessed as having good caring behavior, while another $81 \%$ of nurses caring behavior was not good. Based on the Community Satisfaction Survey (SKM) questionnaire standard while being treated in Non Surgical Class III inpatient rooms in the Bahteramas Regional General Hospital in 2018 in the last three months namely in July amounted to $66.97 \%$, in August $76.59 \%$, and in September by $72.78 \%$. From the results of measurements of community satisfaction treated at Bahteramas Hospital in Southeast Sulawesi Province shows a relatively declining number and does not show an increase, this shows that the care of nurses to patients is not optimal.

Caring behavior is very important for growth and development, improve and improve the conditions or ways of human life (Blais, 2007) Caring contains 3 things that can not be separated, namely attention, responsibility, and done sincerely (Sitorus, 2007). Caring is also an attitude of caring, respecting and respecting others, meaning paying attention and learning one's likes and how someone thinks and acts. Giving care (Caring) simply is not just an emotional feeling or simple behavior, because caring is a concern for achieving better care, caring behavior aims and serves to build social structure, outlook on life and cultural values of different people in one place (Dwidiyanti, 2007), the performance of nurses, especially in caring behavior, is very important in influencing service quality and patient satisfaction, especially in hospitals, where service quality determines the image of service institutions which in turn can increase patient satisfaction and service quality ((potter and perry), 2005)).

Sense of patient dissatisfaction with the care given by nurses is also reflected in the observations and interviews of prospective 
researchers with 10 patients treated in class III in patient rooms that are spread into 4 rooms namely Surgical, Non Surgical, Obgyn, and Perinatology Regional General Hospital Bahteramas. Based on the results of the interview, 7 out of 10 patients said that nurses on duty only perform maintenance obligations such as checking body temperature, measuring blood pressure and other routine activities, while there is no indepth approach from nurses to patients. There is no attention that shows empathy to the patient, so it does not get a deep impression from the patient towards the guards in the inpatient room. It is feared that it will slow down the recovery of patients treated at the Bahteramas Regional General Hospital. In addition, some patients complained about the lack of services such as changing baby bandages and giving drugs that were not on time. From the above phenomenon, researchers are interested in conducting research on "The Correlation between Nurse Caring Behavior and Patient Satisfaction in the Laika Waraka Inpatient Inpatient at the Bahteramas Regional Hospital in Southeast Sulawesi Province in 2019".

\section{METHOD}

This research is an observational analytic research with cross sectional design. This research is the population of all patients in the inpatient ward of Laika Waraka Non Surgical General Hospital Bahteramas, namely 2,595 people in 2017 . The sampling technique in this research is accidental sampling, with a sample size of 67 samples according to the inclusion criteria of inpatients at least- lack of $2 \times 24$ hours. Patients who are not in a state of emergency, patients who can read and write, are cooperative, and patients who are willing to be respondents. The independent variable in this research is caring behavior while the dependent variable is patient satisfaction. Measuring caring behavior uses 4 dimensions, namely the fulfillment of physical, psychological, spiritual, and social needs, which is measured by a Guttman scale questionnaire (Sugiyono, 2010). The questionnaire used the Guttman scale of 20 questions with sufficient and insufficient criteria with objective criteria: respondents answered $<50 \%$ were considered insufficient and $>50 \%$ were considered caring enough. Patient satisfaction in this research is the patient's assessment of the services obtained and felt during treatment. Patient satisfaction can be influenced by caring, caring behavior. Nurses who have a concern in providing nursing care to patients in the hospital are nurses who are caring attitude. This is supported by the theory put forward (Potter and Perry, 2005) that caring is the nurse's wholehearted concern for patients. The assessment was assessed from 5 aspects including, tangible, reliability, responsiveness, assurance, and empathy which was measured using a Guttman scale questionnaire (Sugiyono, 2010), totaling 25 question items. With objective criteria the patients who answer $<50 \%$ are not satisfied and $>50 \%$ of patients are satisfied. Data analysis includes univariate and bivariate analysis. Univariate analysis is performed on each research variable, especially to see the frequency distribution and each variable studied. Bivariate analysis using chi square test with significance level $p<0.005$ and with data processing using computerized $\mathrm{OF}$ SPSS.

\section{RESULTS AND DISCUSSION}

Table 1 showed that of the 67 respondents from the age category, the highest number of respondents was $<50$ years of age as many as 35 respondents $(52.2 \%)$. Whereas with the most gender categories are female sex with the number of 40 people (59.7). While the respondents' characteristics were seen based on their level of education, the highest number of respondents had an elementary school level of 31 respondents (46.2\%). While the smallest number of respondents was respondents with a PT education level of 4 people $(6.5 \%)$. 
Table 1

Respondents' Characteristics of Research

\begin{tabular}{lcc}
\hline \multicolumn{1}{c}{ Respondent Characteristics } & Frequency & Percentage $(\%)$ \\
\hline Age & & 13,4 \\
$17-27$ Year & 9 & 19,5 \\
$28-38$ Year & 13 & 14,9 \\
$39-49$ Year & 10 & 52,2 \\
$>50$ & 35 & 100 \\
\hline Total & 67 & 40,3 \\
\hline Gender & & 59,7 \\
Male & 27 & 100 \\
Female & 40 & 46,2 \\
\hline Total & 67 & 20,8 \\
\hline Education & & 26,8 \\
SD & 31 & 6,5 \\
SMP & 14 & 100 \\
SMA & 18 & 4 \\
\hline College & 67 & \\
\hline
\end{tabular}

Based on table 2 it can be seen that patients who rate bad nurses caring behavior with the largest percentage are in the Spiritual need fulfillment dimension of $56.7 \%$, patients state that nurses focus more on meeting physical needs, while meeting spiritual needs is not good, for example patients do not get religious assistance or prayer. According to the respondent is a nurse service that makes the respondent's complaint diminishes, namely on the dimensions of meeting physical needs, where the measurement results of each dimension are the physical needs dimension obtained from 67 patients, 61 patients $(91.0 \%)$ feel enough with caring behavior especially the dimensions of meeting physical needs and 6 patients $(9.0 \%)$ felt less caring.

Table 2

Respondent Distribution of Caring Aspect

\begin{tabular}{cccc}
\hline Caring Patient & Category & $\mathbf{N}$ & $\boldsymbol{\%}$ \\
\hline \multirow{2}{*}{ Fulfillment of Physical Needed } & Enough & 61 & 91,0 \\
& Lack & 6 & 9,0 \\
\hline Total & Enough & 67 & 100 \\
\hline \multirow{2}{*}{ Fulfillment of Psychological Needed } & Lack & 49 & 73,1 \\
\hline Total & & 18 & 26,9 \\
\hline \multirow{2}{*}{ Fulfillment of Spiritual Needed } & Enough & 67 & 100 \\
\hline Total & Lack & 29 & 43,3 \\
\hline \multirow{2}{*}{ Fulfillment of Social Needed } & Enough & 38 & 56,7 \\
\hline Total & Lack & 67 & 100 \\
\hline
\end{tabular}

Assessment is sufficient as nurses monitor the fulfillment of food and drink needs in accordance with patient needs. If someone is sick, meeting physical needs is very necessary to support the healing of patients because meeting physical needs are the most important to meet basic human needs. This research is in accordance with the Diatmika research at the Bahteramas Regional General Hospital in 2015 about the relationship between the biological needs of patients and satisfaction, from the statistical test, the value 
of $X^{2}{ }_{\text {hit }}=19,862$ is greater than $X_{\text {tab }}^{2}=3,841$ $\mathrm{H}_{\mathrm{a}}$ accepted and $\mathrm{H}_{0}$ is rejected so there is a strong enough relationship between fulfillment patient's physical needs with patient satisfaction. Sufficient assessment on caring aspects according to respondents is nurse service which makes respondent's complaints less and less like nurses listening attentively to patients and nurses provide calm when anxious. The measurement results for each dimension, namely the dimensions of psychological needs were found from 67 patients, 49 patients $(73.1 \%)$ felt quite caring, especially the dimensions of fulfilling psychological needs and 18 patients $(26.9 \%)$ felt less caring. This research is in accordance with the Diatmika research at the Bahteramas Regional General Hospital in 2015 about the relationship between patients' psychological needs and satisfaction, which is from the statistical test, the value of $X^{2}$ hit $=$ 17.264 is greater than $\mathrm{X}_{\text {tab }}^{2}=3,841 \mathrm{H}_{\mathrm{a}}$ accepted and $\mathrm{H}_{0}$ is rejected. Psychological needs with patient satisfaction. Nurse services that make respondents' complaints increasingly reduced, namely the dimension of meeting social needs such as nurses providing sufficient time to communicate with patients, nurses being open and

Table 3

Respondents' Distribution based on 5 Dimension

\begin{tabular}{cccc}
\hline Patients' Satisfaction & Category & $\mathbf{N}$ & $\mathbf{\%}$ \\
\hline \multirow{2}{*}{ Tangible } & Dissatisfaction & 4 & 6,0 \\
& Satisfaction & 63 & 94,0 \\
\hline Total & & 67 & 100 \\
\multirow{2}{*}{ Reliaibility } & Dissatisfaction & 21 & 31,4 \\
& Satisfaction & 46 & 68,6 \\
\hline Total & & 67 & 100 \\
\hline \multirow{2}{*}{ Empathy } & Dissatisfaction & 19 & 28,4 \\
& Satisfaction & 48 & 100 \\
\hline Total & & 67 & 25,4 \\
\multirow{2}{*}{ Responsiveness } & Dissatisfaction & 17 & 74,6 \\
\hline Total & Satisfaction & 50 & 100 \\
\hline \multirow{2}{*}{ Assurance } & & 67 & 29,8 \\
& Dissatisfaction & 20 & 70,2 \\
\hline Total & Satisfaction & 47 & 100
\end{tabular}

Based on Table 3 it can be seen that patients who are dissatisfied with the largest percentage are in the reliability dimension, communicative to patients, nurses provide opportunities for patients to interact with other patients according to the conditions and abilities. The measurement results for each dimension, namely the dimensions of social needs, were obtained from 67 patients, 43 patients $(64.2 \%)$ felt quite caring, especially the dimensions of meeting social needs and 24 patients $(35.8 \%)$ felt less caring. This research is in accordance with the Diatmika research at the Bahteramas Regional General Hospital in 2015 about the relationship between patients' psychological needs and satisfaction, which is from the statistical test, the value of $\mathrm{X}^{2}$ hit $=15.438$ is greater than $\mathrm{X}_{\text {tab }}^{2}=3.841 \mathrm{H}_{\mathrm{a}}$ accepted and $\mathrm{H}_{0}$ is rejected so there is a strong enough relationship between fulfillment social needs with patient satisfaction. Then as many as 23 respondents (34.4\%) who felt the caring assessment was not good. Based on the measurement results of each dimension, especially the dimensions of meeting spiritual needs obtained from 67 respondents 29 patients (43.3\%) felt caring and 38 patients $(56.6 \%)$ felt less caring about the services provided. According to respondents, this assessment is that nurses do not remind patients to worship and nurses do not motivate patients to pray. 
satisfaction, according to respondents is the service of nurses that makes respondents' complaints less and less, namely on the tangible dimension. Based on the measurement results of each dimension, especially tangible dimensions obtained from 67 patients, 63 patients $(94.0 \%)$ were satisfied with the services provided. Satisfied assessments such as clean and neat appearance of nurses and arrangement of treatment rooms / or comfortable and clean examinations. Nurses with a clean appearance, clean uniforms, with a fresh appearance in performing care tasks are expected to be able to change the patient's mood (Kalsum, 2016). Nurse services that make respondents' complaints decrease also in the assurance dimension. From the measurement results of each dimension, especially the assurance dimension obtained from 67 patients, 47 patients $(70.2 \%)$ were satisfied with the services provided. Satisfied assessments such as nurses in providing services, foster enthusiasm and trust to patients, nurses answer well when asked by patients, nurses are always friendly to patients and nurses are skilled in caring. The patient's experience of nursing care, especially the staff's skills in serving patients expressed very satisfied as many as 77 respondents (63.6\%) (Kalsum U, 2016). Complaints of patients, decreasing can also be seen from the dimensions of responsiveness. Based on the measurement of each dimension, especially the dimensions of responsiveness obtained from 67 patients, 50 patients $(74.6 \%)$ were satisfied with the services provided. Such services such as nurses provide fast services when needed, nurses provide clear and easy-to-understand information about illnesses experienced by patients and nurses provide clear information about nursing actions. In the empathy dimension, based on the results of measurements on each dimension obtained from 67 patients, 48 patients $(71.6 \%)$ were satisfied with the services provided. These services are like nurses being patient or tireless towards patients, nurses always smile at patients and nurses care about patient complaints. Then as many as 20 respondents (29.9\%) who felt dissatisfied. This assessment gets on the dimension of reliability. Based on the measurement results on each dimension obtained from 67 patients, 21 patients $(31.4 \%)$ were not satisfied with the services provided. This assessment, according to respondents, is a lack of attention and concern to the client, namely on the reliability dimension, namely the schedule of nurses coming is not clearly informed, and nurses coming up more than 10 minutes when called by the patient. Patient satisfaction with nurse services in the Lotus Care Room of the General Hospital Fatmawati Center in 2016 which also developed five dimensions of satisfaction, namely responsiveness, reliability, assurance, empathy, and tangibles that of the five dimensions, reliability is a dimension that affects patient satisfaction compared to other dimensions that of 81 respondents 34 patients $(42 \%)$ patients who were dissatisfied with the reliabilty dimension (Kalsum U, 2016). In accordance with this research, using the same five dimensions and the reliability dimension also that of 67 respondents there were 21 patients $(31.4 \%)$ felt less satisfied with the reliability dimension. This is because patients who are dissatisfied with officers and services that are not on time. The results of this research are in line with Putra's research (2011) with a sample of 33 respondents who showed satisfaction levels of Class III Inpatient Marwah Ward Yogyakarta PKU Muhammadiyah Hospital showed that the majority of respondents expressed satisfaction as many as 27 respondents (81.8\%) (Putra PP, 2011). Patient satisfaction is the result of patient assessment based on feelings and services that have been provided by nurses or other hospital staff. The quality of services provided by nurses is closely related to the satisfaction experienced by patients as users of hospital services. The satisfaction felt by the patient is not something that happens by itself. This satisfaction occurs because the expectations 
that exist in the patient are fulfilled. Patients assess the level of satisfaction or dissatisfaction they feel after using hospital services.

Table 4

Distribution of Nurses' Caring Attitude and Satisfaction

\begin{tabular}{cccc}
\hline & Variable & f & \% \\
\hline Caring Attitude & & 65,6 \\
Enough & 44 & 34,4 \\
Lack & 23 & \\
\hline Patients' Satisfaction & & 70,1 \\
Satisfaction & 47 & 29,9 \\
Dissatisfaction & 20 & \\
\hline
\end{tabular}

Based on table 4 above shows that of the 67 respondents who had nurses caring behaviors quite good category as many as 44 respondents $(65.6 \%)$ and those who had nurses caring behaviors were less as many as 23 respondents $(34.3 \%)$. While 47 respondents were satisfied $(70.1 \%)$ and 20 respondents $(29.9 \%)$ who said they were dissatisfied.

Based on table 5 above, it shows that of the 67 respondents who rated nurses caring behavior enough and were satisfied as many as 44 respondents $(65.6 \%)$ and those who rated nurses caring behavior were enough and were dissatisfied as much as 0 respondents (0\%). Then of the 67 respondents, who rated nurses caring behavior less and were satisfied as many as 3 respondents (4.6\%) and those who assessed nurses caring behavior were less and were dissatisfied as many as 20 respondents (29.8\%).

Chi Square test results obtained $\mathrm{p}$ value $=$ 0.001 where the value of $p<0.005$ so that obtained $\mathrm{H}_{0}$ is rejected and $\mathrm{H}_{\mathrm{a}}$ is accepted. Of the 67 respondents who rated nurses caring behavior enough and were satisfied as many as 44 respondents $(65.6 \%)$ and those who rated nurses caring behavior were sufficient and were not satisfied as much as 0 respondents (0\%). Then out of 45 respondents, who rated nurses caring behavior less and were satisfied as many as 3 respondents (4.6\%) and those who assessed nurses caring behavior as less and felt dissatisfied were 20 respondents $(29.8 \%)$.
Based on the results of the research obtained from 67 respondents 3 respondents (4.6\%) respondents who rated nurses caring behavior less but they feel satisfied. This happens because in aspects of the dimensions of physical needs such as nurses lacking care of patient hygiene, nurses help meet the needs if they need to defecate and urinate, nurses help you with physical training and fulfill spiritual needs such as reminders to worship, nurses help you in worship and meeting social needs such as nurses providing time to communicate with patients who are not being met. Patients who are satisfied even though the nurses are less caring is also due to the age factor. According to Gunarsa (2008) old age tends to be more satisfied with nursing services compared to younger age because old age is generally more open, so that older patients have lower demands and expectations than younger patients. As a person ages, the wiser in responding to problems so that deficiencies during treatment can be understood (Pondaag Linnie, Rorie P, Hamel R, 2015).

Another thing that affects the level of patient satisfaction is in terms of the characteristics of respondents, including gender, and education level. Based on the results of research from gender factors that assess nurses caring behavior is less and not satisfied most are women. This is consistent with the opinion of Gunarsa (2008) states that, sex has an influence on the views of services provided. Women see more appearance in detail, while men do not heed it. Male gender tends to be more ignorant 
than women, therefore they are considered more flexible than women (Pondaag Linnie, Rorie P, Hamel R, 2015).

In terms of education, according to (Kalsum, 2016), someone with higher education tends to have a higher demand than someone with lower education. Higher education tends to be more demanding or criticizing the service it receives if it does feel dissatisfied with the service compared to people with low education (Pondaag Linnie, Rorie P, Hamel $\mathrm{R}, 2015)$.

Respondents with a lack of judgment on aspects of caring nurses are nurses who do not come immediately when the client asks for help to nurses on the dimensions of psychological needs and in the spiritual dimension that is nurses less reminding clients in worship or motivating clients to surrender to God. While the lack of judgment on aspects of satisfaction is that nurses who are not on time and the schedule of nurses coming is not clearly informed on the Reability dimension.

The results of this research are in line with the research of Ilkafah and Harniah (2017) which states that there is a relationship

\section{REFERENCES}

Blais. (2007). Praktek peperawatan Profesional. Jakarta: EGC.

Dwidiyanti. (2007). caring. Yogyakarta: hasani.

Ilkafah dan Harniah. (2017). Perilaku Caring Perawat Dengan Kepuasan Pasien Di Ruang Rawat Inap Private Care Cantre Rsup Dr Wahidin Sudirohusodo Makassar. Patria Artha J. Nurs. Sci, 1(1). retrieve from: http://ejournal.patriaartha.ac.id/index.php/jns/article/view/4 3

Jacobalis, S. (1995). Liberalisasi Bisnis Jasa Kesehatan dan Dampaknya Bagi Rumah Sakit Indonesia. Jakarta. between caring nurses and the level of patient satisfaction in the Private Care Center Inpatient Room of Dr. Wahidin Sudirohusodo Makassar Hospital with a value of $p=0.006$ (Ilkafah and Harniah, 2017).

\section{CONCLUSIONS AND SUGGESTIONS}

The conclusion of the research showed that there was a relationship between nurses caring behavior with patient satisfaction in the Laika Waraka Non-Surgical Inpatient Hospital Bahteramas of Southeast Sulawesi Province. It is recommended that the hospital to maintain, or increase the quality and time of nursing services to the satisfaction of service users and minimize the number of nursing staff with the number of patients available so that nursing services are provided evenly and patients feel satisfied and all their needs are met.

In this research has weaknesses in the method of data collection using a questionnaire, for the next researcher can continue the research with other approaches, including data collection with direct observation so that it is more valid.

Kalsum, U. (2016). Hubungan Perilaku Caring Perawat dengan Kepuasan Pasien di Ruang Perawatan Teratai Rumah Sakit Umum Pusat Fatmawati tahun 2016. Retrieve from: http://repository.uinjkt.ac.id/dspace/bit stream/123456789/32964/1/UMI\%20K ALSUM-FKIK

Kalsum U. (2016). Hubungan Perilaku Caring Perawat dengan Kepuasan Pasien di Ruang Perawatan Teratai Rumah Sakit Umum Pusat Fatmawati tahun 2016. Retrieve from: http://repository.uinjkt.ac.id/dspace/bit stream/123456789/32964/1/UMI\%20K ALSUM-FKIK 
Pondaag Linnie, Rorie P, Hamel R, S. (2015). Hubungan Komunikasi Terapeutik Perawat Dengan Kepuasan Pasien Di Ruang Rawat Inap Irina A RSUP PROF. DR. R. D. KANDOU $M A N A D O$. Retrieve from: https://ejournal.unsrat.ac.id/index.php/j $\mathrm{kp} / \mathrm{article} / \mathrm{view} / 5171$

potter and perry. (2005). fundamental of nursing (6th ed.). usa: elsevier.

Putra P.P, S. (2011). Hubungan Perilaku Caring Perawat dengan Tingkat Kepuasan Pasien Rawat Inap Kelas III di Bangsal Marwah RS PKU Muhammadiyah Yogyakarta. STIKES 'Aisyiyah Yogyakarta.

Sabarguna BS. (2005). Sistem Informasi Manajemen Rumah Sakit. Konsorium RSI Jateng Dan DIY. Yogyakarta.

Shirly, T. N. (2012). Surgical Patiens, Satisfaction of Nursing Care at the orthopedic Wards in Hospital Universiti Sains Malaysia. Health and Envirotment Journal, 3(1). Retrieve from:www.hej.kk.usm.my/pdf/HEJVol .3No.1/Article05.pdf

Siswati S. (2002). Perilaku Caring Perawat: Pendekatan Watson Di Ruang Mawar Rumah Sakit Umum Daerah DR. Harjono Ponorogo. Universitas Muhammadiyah Ponorogo. http://eprints.umpo.ac.id/892/

Sitorus. (2007). Model Praktik Keperawatan Profesional di Rumah Sakit. Jakarta: EGC

Sugiyono. (2010). Metode Penelitian Pendidikan Pendekatan Kuantitatif, kualitatif, dan $R \& D$. bandung: alfabeta.

Supartiningsih. (2017). Kualitas Pelayanan Kepuasan Pasien Rumah Sakit: Kasus pada Pasien Rawat Jalan. Medicoeticolegal Dan Manajemen Rumah Sakit, 6(1). Retrieve from: http://journal.umy.ac.id/index.php/mrs/ article/view/2342
Watson, J. (2005). Caring Science as sacred science. Philadelphia, Pennsylvania, USA: F.A. Davis Company. 
J urnal Aisyah: J urnal Ilmu Kesehatan, 4(2), December 2019, - 52

La Rangki; Ulfah Dayanti; Asriati 